\title{
Situated transdisciplinarity in university policy: lessons for its institutionalization
}

\author{
Pablo Salvador Riveros ${ }^{1}$. Jaqueline Meriño ${ }^{1} \cdot$ Francisco Crespo $^{1}$. \\ Bianca Vienni Baptista ${ }^{2}$ [D
}

Accepted: 28 December 2021 / Published online: 22 January 2022

(c) The Author(s), under exclusive licence to Springer Nature B.V. 2021

\begin{abstract}
Although transdisciplinarity has taken hold in many areas, it is still a concept in its early stages of development in Latin America. We see an emergent opportunity to contribute to the current discussion on transdisciplinarity and its institutionalization at universities. Our specific interest in this paper is to disentangle the conditions under which transdisciplinarity is developed in Latin American contexts and how it can be better implemented within those contexts. Our study focuses on the context of "Latin American Public Universities." We examine the following research questions: (i) How is transdisciplinarity conceptualized in university policy and what are the conditions for its institutionalization? (ii) What lessons can be drawn more broadly from the role of university policy in the process of institutionalizing transdisciplinarity? To address these questions, we take the Universidad de Chile as a case study and apply a qualitative methodology of content analysis of university policy documents in the period 2006-2021. Grounded on empirical data, we elaborate on the concept of "situated transdisciplinarity" that emerges from the interplay between practices and policy at the Universidad de Chile and serves as a tool for future institutionalizing processes. We conclude that the concept of "situated transdisciplinarity" can orient transdisciplinary research policy, by problematizing discourses and perceptions.
\end{abstract}

Keywords Situated transdisciplinarity $\cdot$ University policy $\cdot$ Chile $\cdot$ Academic capitalism . Institutionalization processes

Pablo Salvador Riveros

priveros@uchile.cl

Jaqueline Meriño

jaqueline.merino@uchile.cl

Francisco Crespo

francisco.crespo@uchile.cl

Bianca Vienni Baptista

bianca.vienni@usys.ethz.ch

1 Unidad de Redes Transdisciplinarias, Vicerrectoría de Investigación y Desarrollo, Universidad de Chile, Diagonal Paraguay 265, Santiago, Región Metropolitana, Chile

2 Transdisciplinarity Lab, Department of Environmental Systems Science, Swiss Federal Institute of Technology, Universitätstrasse 16 - CHN K76.2, 8092 Zürich, Switzerland 


\section{Introduction}

The pandemic and the consequent social and economic crisis manifest themselves as a turning point for contemporary society and its globalization. In this context, the role of higher education institutions is to be a space that responds to the demands of society. The complexity of the current scenario makes transdisciplinarity (TD) and its institutionalization more relevant, as it can shed light on the conception of what constitutes a university.

In 2015, Lawrence took stock of the state of the art in transdisciplinary education and research, considering its ubiquitous use in the natural and social sciences and the humanities. That article was published 10 years after the first special issue about TD in the journal of the Institute for Scientific Information (currently the Web of Science, WOS) and 45 years after the concept was first mentioned in a seminar sponsored by the OECD (Apostel et al., 1972). The exponential growth of publications about TD (Huutoniemi et al., 2010) and TD's integration in the mainstream of contemporary research and teaching contrast with its almost null legitimization in some latitudes. The majority of transdisciplinary voices corresponds to perspectives found in the Northern Hemisphere, thus failing to take notice of the profound asymmetries that shape higher education scenarios in Latin America, affecting the relationship between the university and society. To bridge this gap, this article analyzes the "situated" point of view of the concept of TD.

We aim at contributing to the current discussion on transdisciplinarity and its institutionalization at universities (Gibbs, 2017; Vienni Baptista \& Rojas-Castro, 2019). Our specific interest in this paper is to disentangle the conditions under which TD is developed in Latin American contexts and how it can be better implemented within those contexts. Currently, few studies offer an in-depth analysis of TD institutionalization processes and the specific tensions that arise between policies and practice (Gibbs, 2017).

Our study focuses on the context of "Latin American Public Universities" (LAPU) of which the Chilean case is paradigmatic. The Universidad de Chile (UCH) represents the tension between the conception of the public and the private: it operates in a framework marked by a high rate of privatization (only $7 \%$ is financed by the state), a high number of competing stakeholders, and increasing requirements of self-financing all within the context of a university that values its public mission.

We examine the following research questions: (i) How is TD conceptualized in university policy and what are the conditions for its institutionalization? (ii) What lessons can be drawn more broadly from the role of university policy in the process of institutionalizing TD? To address these questions, we take the Universidad de Chile as a case study (Yin, 2004) and apply a qualitative methodology of content analysis of university policy documents in the period 2006-2021 (Schreier, 2014). Our study explores the understanding of the concept of TD at UCH and the embeddedness of transdisciplinary practices in the institutional environment. Grounded on empirical data, we elaborate on the concept of "situated transdisciplinarity" that emerges from the interplay between practices and policy at $\mathrm{UCH}$ and serves as a tool for future institutionalizing processes.

In the Latin American context, this interplay illustrates the relationship between the university and the society (Slaughter \& Rhoades, 2004; Sigahi \& Saltorato, 2020). This establishes the framework from which we approach TD to illuminate the viewpoint the university holds of itself as a "transformative university" (Guzmán-Valenzuela, 2016) and the nature of TD within this context.

This paper is organized as follows. First, we present an overview of the concept of TD considering its main characteristics. We then analyze four dimensions of TD at UCH. Next, 
we present the main results obtained from the analysis and discuss the challenges of TD within the framework of UCH policies. Finally, we conclude by elaborating on the characteristics of the concept of "situated transdisciplinarity," its relevance in the Latin American context, and future lines of research.

\section{Rationale}

Transdisciplinarity refers to collaborative and integrative praxis grounded in different ways of knowing (Felt et al., 2013; Lang et al., 2012). There are different understandings of the term TD if we compare countries and theoretical approaches (Gibbs, 2015). Klein (2014) discerns three underlying discourses of TD. The third discourse - the problem-solving discourse-acknowledges growing concerns about the science-society interface and how to address societal challenges in a meaningful manner (Gibbs, 2017; Lawrence, 2015). This problem-solving discourse constitutes a pragmatic approach (Pohl, 2008) and is what concerns us here. It conceptualizes TD as a tool for tackling complex situations, considering $\mathrm{TD}$ as a reflexive, integrative, method-driven scientific principle that relies on integrating knowledge from various scientific and social bodies of knowledge (Hirsch Hadorn et al., 2008; Lang et al., 2012; Pohl \& Hirsch Hadorn, 2008).

Transdisciplinary processes of knowledge production involve practitioners - stakeholders-who are representatives of sectors of society beyond the academy (Pohl et al., 2021). These processes are relevant as they bring together diverse societal actors and their perspectives, knowledge, and forms of expertise to approach so-called societal challenges, such as sustainable development, migration, or the current COVID-19 pandemic. Problemsolving TD is characterized by (i) inter-sectoral collaborations, (ii) context sensitivity, and (iii) an orientation towards transformation.

We take TD as a form of problem-solving and as a starting point to conduct the study of $\mathrm{UCH}$. To do this, we define TD through a set of principles recognized by the literature as main features for this type of research (Pohl \& Hirsch Hadorn, 2008; Pohl et al., 2017): (i) the complexity of the issue or problem at stake, (ii) integration of societal actors and scientific actors (mainly researchers) with diverse perceptions, (iii) integration of different types of knowledge, and (iv) integration of different disciplinary perspectives. From this point of view, the discourse on TD is related to the concept of interdisciplinarity (ID), which refers to integrative research among different disciplines or fields of knowledge (National Academy of Sciences, 2005). In this way:

ID typically focuses on a complex problem, question, or topic in activities ranging from individual borrowing across disciplines to large-scale, team-based initiatives.

The scope varies, though, from Narrow ID involving disciplines with compatible methods and epistemologies - e.g., mathematics and physics - to Broad ID bridging disparate approaches - e.g., chemistry and history. (Pohl et al., 2021: 19)

To complement this understanding, we follow Felt et al. (2013) in considering TD as a knowledge regime that comprises different articulations of three components: (i) epistemologies, ideologies, and myths; (ii) institutions and their institutional logics; and (iii) researchers and societal actors who govern the research. To gain a more profound understanding of the complex dynamics at work concerning TD, careful investigation of its concrete and specific conditions and features is needed, along with the concrete intertwinements of (social) imagineries, structures (institutions, programs, careers, etc.), and people 
(Felt et al., 2016). In our study, we focus on the second of three components which TD comprises - institutions and their institutional logics - to disentangle university policies in relation to transdisciplinary knowledge production processes at $\mathrm{UCH}$. This places us in a situated perspective that, due to its particularities, outlines the reconfiguration of the concept of TD as it relates to the vision of the university as an active and transforming entity in society.

In Latin America, some authors have disentangled the concept of TD in search of an adequate perspective for the local context (Bursztyn, 2004; Max-Neef, 2005). Streck (2021) acknowledges differences in definitions of TD but argues for an international understanding of the concept from the perspective of Latin America. However, he also notes that historical and geographical contexts and conditions shaped possibilities and limits in institutionalizing TD in the region. In Chile, Max-Neef (2005) is one of the most renowned authors who has contributed to transdisciplinary theory and practice in the region (e.g., Conde \& Gómez, 2011; Conde et al., 2010) and internationally (Mitchell et al., 2015). Max-Neef (2005) noted that a few transdisciplinary efforts at universities exist but mainly as marginal experiences not integrated into the higher education structure. Thus, there are few contributions to the epistemological discussion on how TD is institutionalized at universities in Latin America, the forms of validation within the university context (i.e., Bursztyn, 2004; Vienni Baptista et al., 2018), and teaching and education (Oliva-Figueroa et al., 2014).

\section{Setting: higher education in Latin America}

Our analysis is framed within a Latin American university that, as such, shares certain characteristics with the higher education system of the continent, i.e., sudden reconfigurations of higher education systems, the appearance of new societal actors who increase the private supply of universities (Ball \& Youdell, 2007), the decrease of available public funds for the academic sector (Aavik, 2019; Arocena \& Sutz, 2005), and the university under market dynamics (Clark, 1998; Slaughter \& Leslie, 1997, 2001). These aspects have brought the public mission of the university to the fore, especially in countries where higher education institutions act as support for their Nation States, and as spaces for interaction between university and society (Ordorika, 2013).

The concepts of "Latin American Public University" (LAPU) and "macro-university" are associated with definitions such as "flagship university" and "university committed to the State" (Ordorika, 2013). These systematize common elements of the Latin American universities, as they accompanied and developed along with their Nation States (Fischman \& Ott, 2018; Ordorika, 2013). Among their main characteristics, there is a strong institutional culture that advocates the relationship between the public sector and the society (Fischman \& Ott, 2018).

Although this type of university constitutes a heterogeneous body of institutions, it presents common intrinsic elements (Fischman \& Ott, 2018):

1) Their role in the construction, expansion, and consolidation of the respective Nation States (Ordorika \& Pusser, 2007; p.192) and their intellectual and social legitimacy (Serrano, 2016).

2) Their function providing outreach education and its potential relationship with TD (Streck, 2021) as a way to approach societal problems (Fischman \& Ott, 2018). 
3) The insertion of the educational system in the context of a highly market-driven economy (Bellei, 2015) that makes implementing long-term collaborative research formats difficult because it collides with a more individualist culture promoted by the market (Riveros et al., 2018). This high level of privatization is a phenomenon that has occurred in the higher education system over the last 40 years (Brunner, 2008; Cox, 1996; Garretón \& Martínez, 1985; Pitton, 2007; Salazar \& Leihy, 2017). In this situation, public institutions seeing their direct state revenues diminished are forced to compete for funds in research, where private institutions generally dominate given their comparative advantages (Taylor, 2016).

The UCH shares these elements. However, the UCH is also one of the most privatized higher education systems in the world (Levy, 2018). After the return to democracy in the 1990s, UCH was fragmented, underfunded, and governed by the old statutes of the 1980s drawn up by members of the military regime. It was not until 1997 that a strong mobilization by students and academics pressured the university to form a committee to change these statutes, which triggered the university's first reform in 2006. This reform, however, was not enough to counteract the weight of 20 years under military regime: although some changes were reversed, the fragmentation of the institution at the national level and the low state funding have been and still are factors that push forward a private management logic.

The worldwide opening and privatization of university enrollment and the progressive decrease in public funding are factors that forced changes in the structural conditions of public universities (Slaughter \& Taylor, 2016). This context has weakened the meaning of a "public" university with a public mission (Brunner et al., 2018) challenged by the growing processes of academic capitalism that imply the orientation of its mission and functions towards the market (Fernández, 2009; Slaughter \& Taylor, 2016). Although it is a public institution, UCH is funded and managed as if it were a private university. Its dynamics show the conflict between the public vision, represented by the public ethos, and the market viewpoint that in practice contradicts such ethos. This has influenced how TD is institutionalized and the structure of university policy.

At present, UCH concentrates most of the country's R\&D productivity (about $20 \%$ of Chile's total scientific productivity). At the same time, UCH receives only $6.74 \%$ of its total budget from the State (excluding grants and tuition vouchers) (CRUCH, 2016), which forces a management model oriented towards self-financing. All of the above acts to explicitly limit the university's public mission also understood as the "third mission" or "university outreach" which entails a "social service." In a specific way, the University Statutes—in their second and third articles—define this third mission as:

The generation, development, integration and communication in all areas of knowledge and domains of culture constitute the mission and foundation of the activities of the University, form part of the complexity of its tasks, and orient the education that it imparts. (Statutes of the Universidad de Chile, 1982/2007 art. 2) ${ }^{1}$

In fulfilling this work, the University responds to the requirements of the Nation by establishing itself as an intellectual reserve characterized by a social, critical and ethically responsible conscience and recognizing as part of its mission the attention to the problems and needs of the country. (Statutes of the Universidad de Chile, 1982/2007 art. 2)

\footnotetext{
${ }^{1}$ UCH documents are in Spanish. All UCH texts quoted in this paper are our translations.
} 
In other words, the third mission of the university is directly linked to the consolidation of the country's identity, and as such the idea of its "public mission" is conceptualized in UCH policy documents. This vision of the university's third mission is assimilated in its approach to complex problems as one of the components of TD. Indeed in the last decades, many universities in Latin America, such as UCH, have embedded TD in their policy documents as a means to achieve societal transformation (Vienni-Baptista et al., 2020).

The UCH, just like other large Latin American universities, was born and developed alongside the process of nation-building (Serrano, 2016). The neoliberal reforms and the expropriation of its regional branches left the UCH confined to the metropolitan region at the same time as state resources were being sharply reduced. UCH, however, continued to occupy the place of the great state university of the country, hegemonizing the spaces of university research and outreach through its extension programs. Although this seems a distinctive element, the reform processes of the Latin American higher education systems occurred in close connection with the expansion, diversification, and privatization of systems (García Guadilla, 2003). These reforms implemented in Chile in the eighties were also reflected in Argentina, Mexico, Peru, and other countries in the region in the nineties (Bernasconi \& Celis, 2017). The current picture of the tensions at the UCH and its public mission reflect the near future of the tensions to which the Latin American public university will be subjected. Thus, the trends that drive the reforms of higher education systems in the world have omnipresent representations in Latin America. Elements such as overcrowding and stratification, competition for public funds, privatization, and budget controls are just some that make up the future of the Latin American public university (GuzmánValenzuela et al., 2021). In this context, our study can contribute to the discussion on transdisciplinarity as a means to promote changes at the institutional level.

\section{Methods}

To answer our research questions, we apply a qualitative methodology (Russell, 2006; Denzin \& Lincoln, 2018) taking UCH as a case study (Yin, 2004). Data was collected from the strategic documents that define the Universidad de Chile's policy. Inclusion criteria were defined according to the following typology:

1. Documents on regulations: These are documents that have a legal nature, linked to the legislative institutionality of the State of Chile. They establish binding standards and commitments and shape the university hierarchy and its basic organizational structure to be implemented within the UCH.

2. Institutional evaluation documents of these policies are also included, which, in turn, establish new institutional commitments: They are binding in nature and guide the work of the different administrative levels. These documents correspond to the main strategic policy documents with regard to teaching, self-disclosure of university activity, and the Institutional Development Plan. One example of this type of document is the Educational Model (Universidad de Chile, 2018a). This university policy document lays the foundation for teaching activities at $\mathrm{UCH}$. It exemplifies the theoretical foundations, the educational vision, and the parameters for teacher evaluation that the university seeks to implement. Another relevant example is the Institutional Development Plan (Universidad de Chile, 2017) that sets institutional objectives for a 5-year term. This document addresses the following topics: academic work, research, artistic creation, government, 
management, budget, outreach and communications, internationalization, and educational projects. It is evaluated at the end of its 5-year period, expecting progress in each of its areas.

3. Interdisciplinary and transdisciplinary incentive documents: This category represents the specific efforts made to encourage inter- and transdisciplinary work at the UCH in the period 2006-2015. These documents are diverse, including (i) funds intended for collaborative work (e.g., National Interest Program, Domeyko Program, and U-Redes Fund) and (ii) documents that account for internal policies to encourage TD, with proposals for university authorities, among others. In 2015, the Unit for Transdisciplinary Networks (Unidad de Redes Transdisciplinarias) was created within the Vicerrectoría de Investigación y Desarrollo (VID, Vice Rector of Research and Development). The Unit's mission is to promote and deepen transdisciplinary work within the UCH, linking academic work with groups of civil society, stakeholders, and decision makers to create networks focused on a wide variety of complex problems. Likewise, the Unit is in charge of promoting relationships between different disciplines and faculties of the UCH, supporting the organization of academic groups for the consolidation of transdisciplinary networks. The Unit is also responsible for the organization of seminars and workshops with the participation of authorities and social leaders, spaces for participation that culminate in the publication of documents contributing to the public debate on public policies.

4. Academic documents: This category has a heterogeneous nature, which expresses - from different viewpoints - how TD has the quality of bidirectionality between institutionality and the academic groups. While the documents on incentives express the will of central authorities to incentivize ID and TD in a general way, these texts correspond to expressions of distinct academic groups that practice ID and TD in their daily activities. These groups are organized in two types: (i) the programs and (ii) the academic networks. The programs (i) are created via University Decree, which specifies their leadership and some aspects of their operation. The programs are provided with an annual budget and an unlimited duration. Examples of such programs are the Risk Reduction and Disaster Program (CITRID, 2017) and the Global Health Program (Programa de Salud Global, 2020). A specific number of programs receive direct support from the Unit for Transdisciplinary Networks. Programs deal with problems such as the location of homes in areas vulnerable to natural disasters and the relationship between health measures and respect for human rights. Academic networks (ii) depend on the will of the academics who work in specific problem areas. Their financing comes indirectly from the operating budget of the Unit for Transdisciplinary Networks. Examples of academic networks are the Interdisciplinary Network on Aging (REDEN) and the Transdisciplinary Group for Obesity (GTOP). These networks have no established duration, and without institutional support, they often dissolve over time. The available support consists of administrative help, organization of meetings, dissemination of information, and methodological advice on participatory techniques. Many networks are focused on problems considered priorities in the Chilean scenario: natural disasters, obesity, aging, labor issues, human rights, and health. The objective is to influence the discussion on these topics at the national and regional levels. Concrete examples of this influence include the publication of documents directed to the Constitutional Convention, participation in sessions of the Chilean Senate, and involvement in creating the National Plan for Dementia (MINSAL, 2007). Academic networks have also produced relevant documents such as the framework elaborated by the Transdisciplinary Network on Aging (REDEN, 2014), and the 
report on "Gender and Public Policy: a necessary view of aging" (2019a) by the same network.

These four types of documents are hierarchically related. The documents on standards and regulations (i) are those at the top of the hierarchy, established by law, that are binding and mandatory. University policy documents (ii), for their part, derive from the standard and regulatory documents, expanding on them to detail the mechanisms for evaluation and follow-up. Finally, the incentive and academic documents (iii and iv) share a similar hierarchical level: they are not binding and serve as internal guidelines.

Based on a theoretical sampling (Martínez-Salgado, 2012; Strauss \& Corbin, 1998), we analyzed all documents available in the period 2006-2021 using a qualitative content analysis approach (Schreier, 2014). The data analysis was carried out in two phases. The first phase focused on scanning the documents to identify the presence or absence of the concept of TD and its main elements: (a) societal actors, (b) complex problems, and (c) collaborative research practices.

In a second phase, we created a content analysis matrix. For this procedure, thirty-five documents were analyzed line-by-line, and four categories were considered in relation to the problem-solving understanding of TD:

1. Conceptualization of TD: Considering the scientific literature (Klein, 2014; Osborne, 2015; Pohl, 2008; to name a few), we analyzed the use of the concept of TD and its variants and components.

2. Definition of complex problem: The prevalence of wicked problems (Sardar, 2010) or complex problems in contemporary society constitutes a main feature within conceptualizations of TD (Klein, 2014). These problems are associated with topics "of social interest" beyond the limits of the academy (Lang et al., 2012; Pohl, 2008).

3. Roles of societal actors: TD recognizes that different societal actors are producers of knowledge and hold a substantial role in the integration process (Felt et al., 2016; Hirsch Hadorn et al., 2008). From the definition of "Mode 2" knowledge production (Gibbons et al., 1994; Nowotny et al., 2001), contextual, territorial, and co-produced knowledge is validated in line with a public debate (Jasanoff, 1987).

4. Collaborative research practices: These are a fundamental feature of transdisciplinary knowledge. TD has its foundations in the collaboration and integration of different disciplines in knowledge production processes (Pohl et al., 2021). In this sense, different authors have developed specific methodologies and tools for transdisciplinary work (e.g., Bammer et al., 2020, Defila \& Di Giulio, 2015; Pohl \& Wuelser, 2019; Young et al., 2014) that seek to strengthen particular communicative and cognitive skills to synthesize different perspectives on a problem and formulate strategies for its resolution (Pohl \& Hirsch Hadorn, 2008).

\section{Findings}

In what follows, we detail the analysis of each dimension and compare them for the four groups of analyzed documents. 


\section{Conceptualization of TD}

A progression of the concept of TD is observed in the documents analyzed (between 2006 and 2021). The term TD appears for the first time in the University Statute in 2006, through the explicit mention of academic collaboration and in relation to the public mission of the university as shown in the following quote:

The academic structure [...] should, especially, promote the functional and territorial integration of the University, transdisciplinarity and the transfer between basic and applied knowledge, as well as the development and improvement of [university and society] members. (Statutes of the Universidad de Chile, 1982/2007, art. 35) ${ }^{2}$

Although the conceptualization of TD appears as an action that it is promoted, it lacks content or definition. The concept was not actually applied until 2015 by the Vice Rector's Office for Research and Development, through the Unit for Transdisciplinary Networks. This Unit represents the first effort to institutionalize, promote, and develop TD at $\mathrm{UCH}$. With the consolidation of this Unit, the concept of TD (stated in policy documents) acquired theoretical content and was embedded in further university policy documents, research, teaching, extension, and internationalization initiatives. The following quote makes this explicit:

In the first case, it comprises the strategic axes of the increase and consolidation of inter-institutional ties, the generation of multidisciplinary dialogues at the international level, the deepening of ties with academics who are international benchmarks, and the impact of internationalization on transdisciplinary research. (Universidad de Chile, 2018b, p. 263)

In UCH framework documents, such as the Institutional Development Plan (Universidad de Chile, 2017), TD constitutes a relevant element. It is also linked directly to the university role defined as:

Development of teaching, research, creation and extension education with high quality, social commitment and public responsibility; wide, harmonious and unrestricted cultivation of scientific, humanistic, artistic and technological disciplines; and promotion of the necessary inter- and transdisciplinary dialogues, both within the University and with external actors. (Universidad de Chile, 2017, p. 15)

With respect to teaching, we analyzed the Educational Model (Universidad de Chile, 2018) as a framework document at UCH. However, this document does not detail any specific transdisciplinary policies linked to classroom teaching practices, curricula development, or students' training. TD appears as a tool to fulfill the institution's public mission, namely that of training professionals to address the country's problems, as shown in this quote:

Continuing with the mission of contributing to the country's development also requires strengthening the capacity to generate deeper ties of cooperation in research and undergraduate and graduate education with related institutions in different parts of the world. This entails the need to address, from an integrative and transdiscipli-

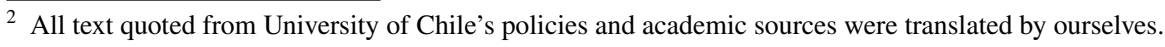


nary perspective, the problems of development at local, national, regional and global levels. (Universidad de Chile, 2018a, p. 16)

Although there is no generalized effort to integrate the transdisciplinary approach to teaching practice, the different transdisciplinary academic networks coordinate elective courses that are available to all UCH students. These are known as "general training courses," and they are transversal to the curricular frameworks of all careers. At present, there are only three courses with transdisciplinary characteristics, which illustrate the incipient nature of the discussion on transdisciplinary teaching at the university. There is no institutional vision that integrates transdisciplinarity in the undergraduate training of any career.

In most of the documents analyzed, TD appears as a highly cited or referenced concept, but it lacks clear limits to differentiate it from other modes of collaborative knowledge production. It was not until the development of specific initiatives (programs and networks, among others) promoted by the VID that it became necessary to advance in defining TD:

Reciprocally, transdisciplinary research around a topic of this importance should strengthen the university community itself, stimulate the formation of new research teams, new specific large-scale projects and new designs for training the professionals and specialists the country urgently needs, as well as contribute to the formulation of new public policies. (REDEN, 2014, p. 5)

The conceptualization of TD has progressed towards more specific dimensions through the support and management of the Unit for Transdisciplinary Networks. The following quote shows this effort:

[The Unit seeks to] coordinate and link the existing academic capacities at the Universidad de Chile in a transdisciplinary perspective, in collaboration with other national and international universities, as well as in dialogue with public institutions and decision makers, civil society, and technological innovators and private actors. (CITRID, 2017)

In the academic documents, TD is defined mainly by two elements. First, there is a new interpretation of the idea of "public mission" that all LAPUs pursue. This explicitly refers to the need to approach "wicked problems" (Sardar, 2010) or societal challenges that the nation faces. The second aspect considers the active participation of societal actors in the construction of public policies and knowledge production processes.

Other relevant features of the TD concept at $\mathrm{UCH}$ include the following:

a) The relevance of UCH's political approach to TD: The term TD is first mentioned in the University Statutes in 2006 (Statutes of the Universidad de Chile, 1982; Universidad de Chile, 2017). This document was approved by the University Senate, the only body with democratic representation of the different levels of the university. This body also prepares the Institutional Development Plan, which in its most recent version (Universidad de Chile, 2017) makes numerous references to the term TD, but without delving into the underlying definition or any relationship to teaching activities. TD is also promoted in different university activities - in an incipient manner-by the Office of the President of the University in the periods 2014-2018 and 2018-2022.

b) The cross-cutting nature of the transdisciplinary approach: The progressive validation of the concept of TD at UCH has been modified over time and rooted in the actions of 
the institution, as it has adapted to the different narratives, actors, and visions of the university through the Office of President of the University, the University Senate, and other independent academic initiatives (e.g., Statutes of the Universidad de Chile, 1982/2007; Institutional Development Plan, 2017 and Working Document "Framework for a Transdisciplinary Approach to Aging in Chile," 2014). The following quote is indicative:

Transdisciplinarity can be understood as a focus on research carried out with the collaboration and integration of researchers and actors who are not necessarily linked to the academic world, with the objective of approaching complex social problems through the collective construction of knowledge. (Universidad de Chile, 2021, n/p)

Another element that shows the cross-cutting nature of TD in the policy documents is the explicit mention of TD in the formation of students at $\mathrm{UCH}$, which, although it has a declarative character, appears as a tool for capacity-building of professionals who are in tune with the problems of the country.

\section{Definition of complex problems}

This dimension appears as a relatively common element in the scientific literature (e.g., Lang et al., 2012). In our analysis, it is related to the public mission of the university as illustrated in the following quote:

Here we add the requirement of investigative work that it be pertinent and whenever possible transcend specific disciplines to creatively tackle national or global problems in a transdisciplinary manner. (Universidad de Chile, 2018b, p. 75)

The hierarchical linkage between the statutes and the other declarations of the university demonstrates the intent for "an integral development, balanced and sustainable, contributing to the solution of the country's problems from a university perspective" (Statutes of the Universidad de Chile, 1982; Universidad de Chile, 2017, art. 3). Thus, complex problems appear as part of the conditions that allow the emergence of TD at the UCH. Though the inclusion of complex problems has been essentially discursive as derived from the mission of the university, this connection between complex problems and the university's public mission supports the development of transdisciplinary institutionalization processes. The assimilation of complex problems to the institutional mission appears under different references: country problems, social challenges, and local or global problems. The following quote shows this commitment:

The University has among its fundamental purposes to advance applied research, which is useful for local or global problems, and to promote basic or theoretical research. (Universidad de Chile, 2018b, p. 16)

Since the creation of the Unit for Transdisciplinary Networks, explicit mention has been made of topics associated with global challenges and/or the Sustainable Development Goals (SDGs) (Universidad de Chile, 2015). Thus, a vision of complex problems has evolved since the creation of the Unit and its different networks and has emerged as an intersection between the guidelines of the VID and the academic efforts to align different voices coherent with the institutional mission. 
This vision has permeated the academic networks supported by the VID framing the discourse about TD to approach complex problems, such as risk reduction when confronted with natural disasters, issues related to climate change, food security, and aging. One example can be found in the Report of the Transdisciplinary Network on Aging:

(...) transdisciplinary spaces provide a view of aging from an academic interest but emphasizing more widely the social, cultural, and political relevance of the topic. (REDEN, 2019b; p. 103)

Transdisciplinarity is also conceptualized as an epistemological and methodological approach centered on tackling complex problems, such as those in the foundational document of the Transdisciplinary Group on Obesity (GTOP):

Transdisciplinarity breaks down the habitual barriers of oversimplification of conventional solutions to local and global populations with obesity. TD innovates by adding a spirit of collaboration and excellence, which has a positive impact on rethinking our approach to knowing and the production of knowledge (as much in teaching and research as in relations with society). (GTOP, 2020, n/p)

In fact, the creation of academic networks around complex problems demonstrates how distinct academic groups, endorsed by institutional organisms, construct spaces of convergence. These spaces of collaboration are also where the public mission of the university intersects with societal actors using problem-solving approaches to country-level issues.

\section{Roles of societal actors}

The role of societal actors, not university actors, however, is not clearly stated in the initial processes of TD institutionalization at $\mathrm{UCH}$. Both the statutes and the incentive lines for collaborative research recognize societal actors only as a category or representation: the country, society, and the State, among others. This is evidenced in the Institutional Accreditation Report of Research, Innovation and Artistic Creation (2018), as this quote shows:

Interdisciplinary and transdisciplinary perspectives are fostered, connecting research with the needs of the country, seeking alliances with the State, the private sector and society. (VID, 2018, p. 528)

While its declaratory presence facilitates the emergence of TD at $\mathrm{UCH}$, concern about societal actors appears associated in the form of specific activities, such as workshops, coordination of meetings, or joint working documents. We observed that until 2014, the concept was linked to a conception of societal actors as the "other" who are recipients of university knowledge in an unidirectional flow. After 2014, with the creation of the first proposals of transdisciplinary R\&D efforts, more explicit references to the role of societal actors and their relevance in coordinating the university-society integration process can be found:

[One objective of the Network is...] To make the theme of aging and the elderly in our country visible among the different public and private actors, from a scientific and transdisciplinary point of view, with the distinctive seal of the Universidad de Chile, to protect their rights and sensitize society as a whole. (REDEN, 2014, p. 4)

A progression in the conceptualization of societal actors is evident as more recently $\mathrm{UCH}$ is demonstrating awareness that university actors must share with decision makers 
and civil society the planning, design, management, and evaluation of public policies. This increasing validation of societal actors' knowledge and practices shows the spirit of TD is beginning to take hold.

Along these lines, documents of the networks and programs recognize explicitly the participation of societal actors external to the university, illustrated in the Policy Paper on Oral Health in Seniors of REDEN:

(...) this document proposes a discussion that combines the high-quality research work of Universidad de Chile with a transdisciplinary vision that transcends the limits of the academy, democratizing the space for the production of knowledge and proposals to various actors of civil society and incumbent decision makers both at personal and family, community, national and public policy level. (REDEN, 2019b; p. 10)

This is deepened with the appearance - albeit sporadic - of spaces for interpellation to the academy, recognized as fundamental for transdisciplinary work, in recent publications:

The 'Position Papers' series is a new line of publication of transdisciplinary dialogues of the Vice Rector's Office for Research and Development of Universidad de Chile, which seeks to serve precisely as support around the debate on contingent issues in our country, as well as the spread of and the encounter between perspectives from the academy to the communities and from the communities to the academy. (CITRID, 2020 p. 12)

\section{Collaborative research practices}

Collaborative research practices are first mentioned in 2006. These practices appear transversely in documents, in accounts on lines of incentives for research, in the regulatory and policy documents, and in those related to networks. Collaboration is encouraged through instruments that show coherence with the university's regulatory framework, as indicated by the University Statute:

They are also part of these guiding principles (...) and the promotion of dialogue and interaction between the disciplines it cultivates. (Statutes of the Universidad de Chile, 1982/2007, art. 4)

However, given that the mode of interdisciplinary knowledge production still prevails in funding schemes, these collaborative mechanisms do not often contemplate the integration of societal actors, i.e., those from outside the university. For example, documents of a strategic nature such as the Institutional Development Plan detail problems associated with the absence of collaborative practices for the development of research at the university. Certain common elements referred to include (i) the lack of its own funds to promote lines of research at the university, (ii) the low number of collaborative projects, and (iii) the existence of regulations in some large projects with external financing that force research groups to work independently from the university (Universidad de Chile, 2017; p. 10). These problems are the result of the existing asymmetries between academic units and the pressures from research funding agencies, but the Development Plan focuses on ID rather than TD when identifying areas for improvement.

Despite the above, collaborative research practices are emerging most notably in the construction of networks and the recognition that complex problems require a wider pool of ideas and actors. The following quote is indicative: 
This effort responds to a joint action of researchers from different traditions that tries to find points of intersection closer to the complexity of this new world and, once the convergences have been found, promote new ways of approaching problems. That is the essence of transdisciplinarity, and the work presented here is an optimum example of awareness of how the complexity of the problems that the country and the whole of humanity face today cannot be solved from the internal dynamics of a particular discipline, nor from a mere juxtaposition that adds different knowledge, but rather requires their hybridization to generate new approaches. (CITRID, 2021; p. 5)

Unfortunately, although transdisciplinary networks have support from the VID, they are not legitimized spaces for recognition in the academic career for researchers collaborating in them. Thus, their formation responds to the academic will to converge around countrylevel problems as a means to contribute to the country and its development. This intention appears in the documents of the academic networks that act as spaces for visibility outside the university, but also as a product of collaborative practices. However, without funding and deeper support from the university, the lifecycles of these networks may be limited.

\section{Situated transdisciplinarity}

This paper aimed at understanding the challenges of institutionalizing TD in universities based on two questions: (i) how is TD conceptualized in university policy and what are the conditions for its institutionalization? And (ii) what lessons can be drawn more broadly from the role of university policy in the process of institutionalizing TD?

We acknowledge that this study has two main challenges: (i) the UCH constitutes an example of a LAPU, and as such, it shares the features that this type of university has in Latin America, and (ii) UCH also represents the struggle to confront the pervasive drubbing from marketization processes that the region faces. Taking these aspects into consideration, our analysis shows the relevance of TD at UCH as a turning point that can give rise to a phenomenon opposed to the marketization of education mainly through the construction of "in-between" spaces (Bhabha, 2012; Vilsmaier et al., 2017). These constitute "interstices - the overlap and displacement of domains of difference - [in which] the intersubjective and collective experiences of (...) community interest or cultural values are negotiated" (Bhabha, 1994; p. 15). In our study, "in-between" spaces involve academic groups and units within the institution such as the Unit for Transdisciplinary Networks. These spaces help to optimize institutionalization processes by allowing for innovative and collaborative practices to take place, as TD. In this Unit, the relationship between networks and the university administration is consolidated by creating policies that incentivize TD.

To answer the first question, we used UCH as a case study to analyze how TD is integrated into university policy as part of its organic structure. We studied university documents that employ a discourse supporting the public mission. These documents correspond to a narrative that includes various societal actors and institutional levels, such as the Unit for Transdisciplinary Networks, the academic networks (e.g., REDEN and CITRID), and the VID. Documents such as the Educational Model (2018a) and the Institutional Evaluation Document (2018b) are explicit expressions of university policy that use TD to update and give relevance to its institutional mission.

Although TD does not have a homogenous definition within the university, our analysis confirms that four aspects prevail: (i) the aim to approach complex problems that require 
an urgent national strategy, (ii) the integration among different disciplines-trying to build new bodies of knowledge, (iii) the aim of transcending disciplines to approach complex problems, and (iv) the interaction with societal actors. These aspects are manifested in the documents analyzed, where different groups resignify the concept of TD. Thus, TD is situated in relation to the interests of these groups, their topics, and political ambitions.

Indeed, as elaborated on in scientific literature, conflicts appear as TD is included in research funding programs and policy that do not clearly define what is meant by it (Bruce et al., 2004; Lyall \& Fletcher, 2013). An increasing number of programs call for transdisciplinary knowledge production internationally (Graf, 2019) and nationally (ANID, 2020) but lack clear guidelines on how to understand these terms and how to implement projects that adequately use them (Lindvig \& Hillersdal, 2019; Spaapen et al., 2020).

Regarding our second research question, our analysis shows that TD has often been referenced but not clearly defined in the university policy at $\mathrm{UCH}$. This is the main lesson extracted from the Chilean context that influenced the process of TD institutionalization. As the scientific literature has discussed, the misalignment between policy and practice at universities acts against TD's effectiveness to cope with societal challenges (Riveros et al., 2018; Sakao \& Brambila-Macias, 2018). To improve TD's effectiveness through better alignment of policy and practice at the university (Vienni Baptista et al., 2018), we propose a definition of TD that strategically accompanies the development of the concept in Latin American universities, which we call "situated TD."

This concept is defined by a relationship between a social demand external to the university—manifested in the idea of "public mission" (Ordorika, 2013)—and a set of collaborative teaching and research practices. These practices take place in "in-between" spaces (Bhabha, 2012), transcend traditional disciplinary structures, and work tightly with and for societal actors. These spaces are promoted by policies that have evolved over the years from a focus on country problems and are supported by units, such as the Unit for Transdisciplinary Networks at UCH. TD, in this sense, serves as a tool for the creation of these "in-between" spaces where different societal actors can also contribute to the mission of the university.

Situated TD, metaphorically, catalyzes a set of new relationships at the university, optimizing the institutionalization process. TD, upon coming into contact with the public mission, reconfigures the margins of the university's mission, but in the same process, TD mutates and changes its configuration, interacting with this ethos of the institution, transforming itself into a situated practice. In this transformation, situated transdisciplinarity not only describes a relationship (i.e., academia with societal actors interacting as a result of their shared concerns about complex problems that require an urgent and multidimensional approach), but also serves as an instrument to construct a set of practices, legitimize those practices and create spaces that are not yet fully institutionalized. For this reason, we call these "in-between" spaces (Bhabha, 2012). TD situated in this way can be understood as an adjective-which describes-and a verb, representing how it is embedded in the practices carried out by the academic networks and programs. TD is reconfigured by becoming operational as an instrument of knowledge management in daily practices.

As shown in our case study, UCH has openly fostered TD as a dynamic concept that facilitates approaching urgent societal challenges. For example, TD has had an active role influencing the organization of activities and thematic priorities in the National Plan for Dementia (MINSAL, 2007). Through the collaboration of networks, the process of creating a plan was optimized by bringing together academics and knowledge producers from 


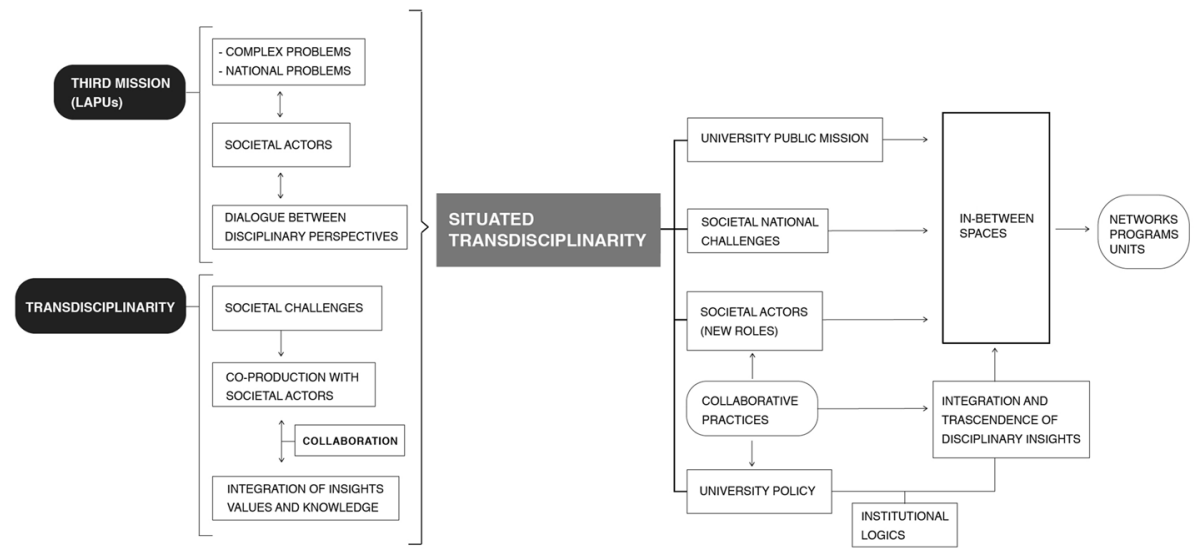

Fig. 1 The concept of situated transdisciplinarity and its components

outside the university. This was an early initiative but one that clearly shows the utility of promoting the concept of situated TD for advancing in problems of national importance.

This conceptualization of "situated TD" allows us to advance the study of the institutionalization processes as it offers a plastic and flexible framework in which policy and practice can be intertwined. At the same time, it allows the transdisciplinary knowledge regime to be framed in the ongoing transformations of scientific timescales and spaces at universities (Felt, 2017; Felt et al., 2013), mostly imposed by academic capitalism and the market-driven context.

Figure 1 illustrates the concept of situated TD that merges the main features of:

a) The third mission (or public mission), which is linked to complex problems and national challenges, this being a feature of the LAPUs.

b) TD as defined in the scientific literature: This notion implies coping with complex problems, through collaborative practices and the co-production of knowledge with societal actors, seeking the integration of perspectives, values, and knowledge (Pohl \& Hirsch Hadorn, 2008).

These two ( $\mathrm{a}$ and $\mathrm{b}$ ) are adapted to and enriched when embedded into the situated condition of TD. Situated TD emerges from the interplay between practices and policy. It has four main interrelated components:

1. The public mission of the university: This feature is not explicitly stated in university policy, but it is its tacit foundation. The third mission generates a demand and an expectation on the part of societal actors towards the university. TD is a means and a tool to interpret and execute actions in view of this tacit social demand.

2. Collaborative practices: They are both a property of TD but also a reality of academic spaces. Transdisciplinary practices develop from the "bottom-up" through academic networks that can evolve into national policies (e.g., REDEN, 2019a). Simultaneously, institutionalized collaborative practices from "top-down," like the VID, support and help the consolidation of new transdisciplinary practices within the programs and networks. 
3. Joint work with societal actors and the consolidation of new roles: Societal actors act as facilitators and active agents of change. These roles are expressed in a diffuse way in the $\mathrm{UCH}$ documents analyzed, but they take a more specific form in practices consolidated to find alternative solutions to grand challenges (e.g., MINSAL, 2007). Their presence is often implicit, but relevant in university policy because they allow the development of co-production processes.

4. University policy: This is generated in iterative cycles that have gradually intertwined the institutional logics (Felt et al., 2016), practices, actors, and the country's mission (translated into societal national challenges). This evolves in a university policy that explicitly considers TD and gives it content and its quality of "situated" contributing to the consolidation of in-between spaces (Bhabha, 2012). According to our findings, the gradual establishment of a transdisciplinary policy within $\mathrm{UCH}$ is characterized by its close relationship with the third university mission. In line with previous studies (Streck, 2021; Vienni Baptista et al., 2018), TD is embedded in the public mission of the university, which has served as an incentive for the development of transdisciplinary research and teaching. In turn, the university policy oriented to the development of TD has generated, as we detailed for the Chilean case, "in-between spaces," such as the academic networks, which have their own academic production around TD, adapting the concept to their needs and creating and recreating the institutional logics.

The concept of "situated TD" is characterized by the overlapping of TD in the heart of the LAPUs and its adaptation to the practices of groups and networks. The interplay between the concept of TD and the public mission of the university does not occur in mere interaction, but rather unfolds during the institutionalization process (Vienni Baptista \& Rojas-Castro, 2019), i.e., in the operationalization of TD as a management instrument and as a criterion for characterizing a mode of knowledge production. Our analysis illustrates this transition, from the spirit declared in the statutes to the explicit inclusion of the concept of TD in the incentive instruments, the Unit for Transdisciplinary Networks, the academic networks, programs, and other academic initiatives reaching into areas of research, development, and teaching.

The concept of "situated TD" is also useful as a policy tool to support TD in institutional settings. The Chilean case study allows us to reflect on the tension between the university platform, evidenced in the policy and documents on standards and regulations, and the daily practices to conduct transdisciplinary research and teaching. As was already proposed, the highly privatized and market-driven context has had a weakening effect on the public mission of $\mathrm{UCH}$. In fact, it is TD that has served to reinterpret and revitalize the university's public mission.

To further foster the success of TD in institutionalizing processes, university administrators need to apply a situated understanding of TD as a means to overcome the disconnection between policy and practice. At present, many transdisciplinary initiatives which may not even be on the radar of university policy makers may disappear from lack of support. However, creating and empowering transdisciplinary units within higher education settings can be a key to solidifying the role of the public university in solving the wicked problems of our present and future. To achieve this synergy, TD needs to be better funded as a means to foster a joint approach that links transformative activities with the aims of the public mission of the university. At the same time, policy makers need to be educated on what TD is and the role it can play in Chile and in the region to better align policy with the university mission and what TD can add towards realizing that mission. 


\section{Conclusions}

The role of the university in Latin America has been resignified in a growing context of academic capitalism (Göransson et al., 2009). The university's organization and its social role have been reconfigured (Slaughter \& Leslie, 1997), especially at the time we are writing this paper given the influence of the so-called "social unrest" in Chile on the one hand, and the socio-health crisis produced by the pandemic on the other. Both crises still in development have a substantive influence on the demands of society towards public education institutions and particularly the UCH. These changes leave a set of questions and paths opened about TD and its relevance in Latin America. However, our analysis shows that the consolidation of TD at the conceptual level is a key element for its institutionalization. The process of progressive assimilation and institutional integration of TD in the LAPUs marks the future of these institutions. In the case of $\mathrm{UCH}$, this process has been characterized by the need for adaptation and coherence with its public mission, derived from its quality as a public university and the nature of an institution committed to the State (Ordorika, 2013).

In an effort to understand how TD fits into the LAPUs, we propose the concept of "situated TD." Here we have outlined elements that can shed light on the process of conceptual adaptation of TD in a public university in Latin America. Situated TD reaffirms and reestablishes the organic and bidirectional relationship with society that was envisioned at the inception of LAPUs. We conclude that the concept of "situated TD" can orient transdisciplinary research, teaching, and policy, by connecting practices, imagineries, and discourses, strengthening the public mission of the university. In the same way, approaching TD from a situated perspective can facilitate the process of institutionalization of TD by intertwining policy and practice. Our example of the Unit for Transdisciplinary Networks at the UCH demonstrates that successful approaches to societal challenges can be developed in the LAPUs even in contexts of high marketization of the educational system as in the Chilean case.

In this context, it is important to build greater understanding among researchers and university administrators through a long-term, sustained, and participatory dialogue together with training a new generation of students to increase awareness of societal challenges (Spaapen et al., 2020). Understanding the processes of integration into university policy of a new knowledge regime such as TD contributes to the discussion on institutionalization and the future of public higher education.

\section{Declarations}

Competing interests The authors declare no competing interests.

\section{References}

Aavik, K. (2019). Crafting neoliberal futures in the strategic plans of Estonian universities. Futures, 111, 148-158. https://doi.org/10.1016/j.futures.2018.10.003

Agencia Nacional de Investigación y Desarrollo (ANID) (2020). Bases Tipo Concurso Institutos Científicos del Programa Iniciativa Científica Milenio, from: http://www.iniciativamilenio.cl/wp-content/uploads/ 2020/01/Bases-Concurso-Institutos.pdf. Accessed Feb 2020.

Apostel, L., Berger, G., Briggs, A., \& Michaud, G. (1972). Interdisciplinarity problems of teaching and research in universities. Interdisciplinarity in Universities. 
Arocena, R., \& Sutz, J. (2005). Latin American universities: From an original revolution to an uncertain transition. Higher Education, 50(4), 573-592. https://doi.org/10.1007/s10734-004-6367-8

Ball, S. J., \& Youdell, D. (2007). Privatización encubierta en la educación. Education International.

Bammer, G., O’Rourke, M., O’Connell, D., Neuhauser, L., Midgley, G., Klein, J. T., Grigg, N. J., Gadlin, H., Elsum, I. R., Bursztyn, M., Fulton, E. A., Pohl, C., Smithson, M., Vilsmaier, U., Bergmann, M., Jaeger, J., Merkx, F., Vienni Baptista, B., Burgman, M. A., ..., Richardson, G. P. (2020). Expertise in research integration and implementation for tackling complex problems: When is it needed, where can it be found and how can it be strengthened? Palgrave Communications, 6(1), 1-16. https://doi.org/10. 1057/s41599-019-0380-0

Bellei, C. (2015). El gran experimento: Mercado y privatización de la educación chilena. LOM Ediciones.

Bernasconi, A., \& Celis, S. (2017). Higher education reforms: Latin America in comparative perspective. Education Policy Analysis Archives, 25(67). https://doi.org/10.14507/epaa.25.3240

Bhabha, H. K. (2012). The location of culture. Routledge.

Bruce, A., Lyall, C., Tait, J., \& Williams, R. (2004). Interdisciplinary integration in Europe: The case of the Fifth Framework programme. Futures, 36(4), 457-470. https://doi.org/10.1016/j.futures.2003. 10.003

Brunner, J. J. (2008). Educación Superior en Chile: Instituciones, Mercados y Políticas Gubernamentales, 1967-2007 (Doctoral dissertation, Leiden University)

Brunner, J. J., Ganga-Contreras, F., \& Rodríguez-Ponce, E. (2018). Gobernanza del Capitalismo Académico: Aproximaciones desde Chile. Revista Venezolana de Gerencia, Esp(1), 11-35.

Bursztyn, M. (2004). Meio ambiente e interdisciplinaridade: Desafios ao mundo acadêmico. Desenvolvimento e Meio Ambiente, 10., from: https://revistas.ufpr.br/made/article/viewFile/3095/2476. Accessed July 2019.

Clark, B. R. (1998). Creating entrepreneurial universities: Organizational pathways of transformation. Issues in higher education. ERIC.

Conde, D., Baliero, W., Biasco, E., Fossati, M., Lorenzo, E., Gorfinkiel, D., Roche, I., Cortazzo, R., Medina, M., Cetrulo, R., Delgado, E., de Álava, D., \& Tejera, R. (2010). Centro Interdisciplinario para el Manejo Costero Integrado del Cono Sur. In clave Inter.(2010). Seminario 'Reflexiones sobre la Interdisciplina en la Universidad de la República'(pp.51-58). Udelar.

Conde, D. \& Gómez, M. (2011). Scientific basis: Relevant knowledge and data for integrated coastal zone management. In Gómez, M., Conde, D., Villarmarzo, R. (Eds) The sustainability of integrated management in the coastal zone of Uruguay: Connecting knowledge to action. ECOPLATA/IDRC.

Consejo de Rectores de las Universidades Chilenas (CRUCH) (2016) Anuario Estadístico 2016. Accessed in June 2021. Retrieved from: https://www.consejoderectores.cl/public/pdf/anuario/2016/ CRUCHAnuario_Estadistico_2016.pdf

Cox, C. (1996). Higher education policies in Chile in the 90s. Higher Education Policy, 9(1), 29-43.

Defila, R., \& Di Giulio, A. (2015). Integrating knowledge: Challenges raised by the "Inventory of Synthesis." Futures, 65, 123-135. https://doi.org/10.1016/j.futures.2014.10.013

Denzin, N. K., \& Lincoln, Y. S. (eds). (2018). The SAGE Handbook of Qualitative Research. 5th ed. SAGE Publications.

Felt, U. (2017). Of timescapes and knowledgescapes: Re-timing research and higher education. In P. Scott, J. Gallacher, \& G. Parry (Eds.), New Landscapes and Languages of Higher Education (pp. 129-148). Oxford University Press.

Felt, U., Igelsböck, J., Schikowitz, A., \& Völker, T. (2013). Growing into what? The (Un)disciplined socialisation of early stage researchers in transdisciplinary research. Higher Education, 65(4), 511-524. https://doi.org/10.1007/s10734-012-9560-1

Felt, U., Igelsböck, J., Schikowitz, A., \& Völker, T. (2016). Transdisciplinary sustainability research in practice: Between imaginaries of collective experimentation and entrenched academic value orders. Science, Technology, \& Human Values, 41(4), 732-761. https://doi.org/10.1177/0162243915 626989

Fernández, E. F. (2009). El sistema-mundo del capitalismo académico: Procesos de consolidación de la universidad emprendedora. Archivos Analíticos de Políticas Educativas/ Education Policy Analysis Archives, 17(1).Redalyc. https://www.redalyc.org/articulo.oa?id=275019727020. Accessed Feb 2020.

Fischman, G. E., \& Ott, M. (2018). Access, equity and quality trends in Latin America's public universities. International Journal of Educational Development, 58, 86-94. https://doi.org/10.1016/j.ijedu dev.2016.11.002

García Guadilla. (2003). Balance de la década de los '90 y reflexiones sobre las nuevas fuerzas de cambio en la educación superior. In Mollis, Marcela (Comp.) Las universidades en América Latina: ¿reformadas o alteradas? La cosmética del poder financiero. Buenos Aires: CLACSO. 
Garretón, M. A., \& Martínez, J. (1985). Universidades chilenas: Historia, reforma e intervención. Ediciones SUR.

Gibbons, M., Limoges, C., Nowotny, H., Schwartzman, S., Scott, P., \& Trow, M. (1994). The new production of knowledge: the dynamics of science and research in contemporary societies. SAGE.

Gibbs, P. (editor) (2017). Transdisciplinary higher education: A theoretical basis revealed in practice. Springer.

Gibbs, P. (2015). Transdisciplinarity as epistemology, ontology or principles of practical judgement. In P. Gibbs (Ed.), Transdisciplinary professional learning and practice (pp. 151-164). Springer.

Göransson, B., Maharajh, R., \& Schmoch, U. (2009). New activities of universities in transfer and extension: Multiple requirements and manifold solutions. Science and Public Policy, 36(2), 157-164. https://doi.org/10.3152/030234209X406863

Graf, J. (2019). Bringing concepts together: Interdisciplinarity, transdisciplinarity, and SSH integration. Fteval Journal for Research and Technology Policy Evaluation, 48, 33-36. https://doi.org/10. 22163/fteval.2019.364

GTOP. (2020). Grupo Transdisciplinario para la investigación, docencia y extensión en Obesidad de Poblaciones (GTOP). Vicerrectoría de Investigación y Desarrollo Universidad de Chile.

Guzmán-Valenzuela, C. (2016). Unfolding the meaning of public (s) in universities: Toward the transformative university. Higher Education, 71(5), 667-679. https://doi.org/10.1007/ s10734-015-9929-z

Guzmán-Valenzuela, C., Queupil, J. P., \& Ríos-Jara, H. (2021). Global and peripheral identities in the production of knowledge on higher education reforms: The Latin American case. Higher Education Policy, 34, 321-343. https://doi.org/10.1057/s41307-019-00134-4

Hirsch Hadorn, G. H., Hoffmann-Riem, H., Biber-Klemm, S., Grossenbacher-Mansuy, W., Joye, D., Pohl, C., Wiesmann, U., \& Zemp, E. (2008). Handbook of transdisciplinary research. Springer.

Huutoniemi, K., Klein, J. T., Bruun, H., \& Hukkinen, J. (2010). Analyzing interdisciplinarity: Typology and indicators. Research Policy, 39(1), 79-88. https://doi.org/10.1016/j.respol.2009.09.011

Jasanoff, S. (1987). Contested boundaries in policy-relevant science. Social Studies of Science, 17(2), 195-230. https://doi.org/10.1177/030631287017002001

Klein, J. T. (2014). Discourses of transdisciplinarity: Looking back to the future. Futures, 63, 68-74. https://doi.org/10.1016/j.futures.2014.08.008

Lang, D. J., Wiek, A., Bergmann, M., Stauffacher, M., Martens, P., Moll, P., Swilling, M., \& Thomas, C. J. (2012). Transdisciplinary research in sustainability science: Practice, principles, and challenges. Sustainability Science, 7(1), 25-43. https://doi.org/10.1007/s11625-011-0149-x

Lawrence, R. J. (2015). Advances in transdisciplinarity: Epistemologies, methodologies and processes. Futures, 65, 1-9. https://doi.org/10.1016/j.futures.2014.11.007

Levy, D. C. (2018). Global private higher education: An empirical profile of its size and geographical shape. Higher Education, 76(4), 701-715. https://doi.org/10.1007/s10734-018-0233-6

Lindvig, K., \& Hillersdal, L. (2019). Strategically unclear? Organizing interdisciplinarity in an excellence programme of interdisciplinary research in Denmark. Minerva, 57(3). https://doi.org/10. $1007 / \mathrm{s} 11024-018-9361-5$

Lyall, C., \& Fletcher, I. (2013). Experiments in interdisciplinary capacity-building: The successes and challenges of large-scale interdisciplinary investments. Science and Public Policy, 40(1), 1-7. https://doi.org/10.1093/scipol/scs113

Martínez-Salgado, C. (2012). El muestreo en investigación cualitativa: Principios básicos y algunas controversias. Ciência \& Saúde Coletiva, 17, 613-619. https://doi.org/10.1590/S1413-8123201200 0300006

Max-Neef, M. A. (2005). Foundations of transdisciplinarity. Ecological Economics, 53(1), 5-16. https:// doi.org/10.1016/j.ecolecon.2005.01.014

MINSAL (Ministerio de Salud) (2007). Plan Nacional de Demencia. Gobierno de Chile. Retrieved from https:/www.minsal.cl/wp-content/uploads/2017/11/PLAN-DE-DEMENCIA.pdf. Accessed Feb 2021.

Mitchell, C., Cordell, D., \& Fam, D. (2015). Beginning at the end: The outcome spaces framework to guide purposive transdisciplinary research. Futures, 65, 86-96. https://doi.org/10.1016/j.futures. 2014.10.007

National Academy of Sciences, National Academy of Engineering, Institute of Medicine (2005). Facilitating interdisciplinary research. The National Academies Press.

Nowotny, H., Scott, P. B., \& Gibbons, M. T. (2001). Re-thinking science: Knowledge and the public in an age of uncertainty. Polity Press. 
Oliva-Figueroa, I., Koch-Ewertz, T., \& Quintero-Tapia, J. (2014). Interdisciplinary/transdisciplinary and the university: Patterns of disciplinary mobility and interactivity. Magis, 6(13). http://hdl.handle. net/10554/26513. Accessed July 2021.

Ordorika, I. (2013). La universidad constructora de Estado en Rodríguez, R. (Ed.), El siglo de la UNAM: vertientes ideológicas y políticas del cambio institucional (pp. 105 - 130). Grupo editorial Miguel Angel Porrua-UNAM.

Ordorika, I; Pusser, B. (2007). La Maxima Cases de Estudios: The Universidad Nacional Autonoma de Mexico as a State-Building University. In Altbach, P; Balan, J; (Eds.), World class worldwide: Transforming research universities in Asia and Latin America. (pp. 189-215) Johns Hopkins University Press.

Osborne, P. (2015). Problematizing disciplinarity, transdisciplinary problematics. Theory, Culture \& Society, 32(5-6), 3-35. https://doi.org/10.1177/0263276415592245

Pitton, V. (2007). Disentangling Chile's authoritarian neoliberalism and its effects: The downfall of public higher education and its implications for equitable access. Critical Studies in Education, 48(2), 249-267. https://doi.org/10.1080/17508480701494267

Pohl, C. (2008). From science to policy through transdisciplinary research. Environmental Science \& Policy, 11(1), 46-53. https://doi.org/10.1016/j.envsci.2007.06.001

Pohl, C., \& Hirsch Hadorn, G. (2008). Methodological challenges of transdisciplinary research. Natures Sciences Sociétés, 16(2), 111-121. https://doi.org/10.1051/nss:2008035

Pohl, C., \& Wuelser, G. (2019). Methods for coproduction of knowledge among diverse disciplines and stakeholders. In K. L. Hall, A. Vogel, \& R. T. Croyle (Eds.), Strategies for Team Science Success (pp. 115-121). Springer.

Pohl, C., Truffer, B., \& Hirsch Hadorn, G. (2017). Addressing wicked problems through transdisciplinary research. In R. Frodeman, J. T. Klein, \& R. C. S. Pacheco (Eds.), The Oxford handbook of interdisciplinarity (2nd ed., pp. 319-331). Oxford University Press.

Pohl, C., Thompson Klein, J., Hoffmann, S., Mitchell, C., \& Fam, D. (2021). Conceptualising transdisciplinary integration as a multidimensional interactive process. Environmental Science \& Policy, 118, 18-26. https://doi.org/10.1016/j.envsci.2020.12.005

Programa de Salud Global (2020). Gobernanza y protección de derechos civiles y políticos en contexto de pandemia COVID-19 . https://doi.org/10.34720/92V5-RY19

Programa de Reducción de Riesgos y Desastres (CITRID) (2017). Voces, convergencias y desafíos en torno a la gestión de los desastres socionaturales. Presentación Programa de Reducción de Riesgos y Desastres Universidad de Chile.

Programa de Reducción de Riesgos y Desastres (CITRID) (2020). Los territorios que habita(re)mos: ¿Qué futuro existe para las zonas de sacrificio? Programa de Reducción de Riesgos y Desastres - CITRID. Vicerrectoría de Investigación y Desarrollo Universidad de Chile.

Programa de Reducción de Riesgos y Desastres (CITRID) (2021). "Reducción del riesgo de desastres y nueva Constitución: hacia una perspectiva pública y transdisciplinar” Programa de Reducción de Riesgos y Desastres. Vicerrectoría de Investigación y Desarrollo, Universidad de Chile.

Red Transdisciplinaria sobre Envejecimiento (REDEN) (2014). Documento Marco para el Abordaje Transdisciplinario al Envejecimiento en Chile. Red Transdisciplinaria sobre Envejecimiento Universidad de Chile. Por un envejecimiento saludable en el Chile del Siglo XXI. Universidad de Chile.

Red Transdisciplinaria sobre Envejecimiento (REDEN) (2019a). Resultados de la Sexta Escuela Internacional de Verano sobre Envejecimiento "Género y Políticas Públicas: una mirada necesaria de la vejez".

Red Transdisciplinaria en Envejecimiento (REDEN). (2019b). "Salud oral en personas mayores: un desafío multidimensional para Chile”. Red Transdisciplinaria sobre Envejecimiento. Vicerrectoría de Investigación y Desarrollo Universidad de Chile.

Riveros, P., Rivas, I., Liberona, F., \& Meriño, J. (2018). Estrategias de fomento al trabajo colaborativo en la Universidad de Chile en un contexto de privatización y mercadización del sistema de educación superior nacional ClimaCom-Inter/Transdisciplinaridade, 5(13). http://climacom.mudancasclimaticas.net. br/?p=9942. Accessed Feb 2020.

Russell, B. (2006). Research methods in anthropology: Qualitative and quantitative approaches (4th ed). AltaMira Press.

Sakao, T., \& Brambila-Macias, S. A. (2018). Do we share an understanding of transdisciplinarity in environmental sustainability research? Journal of Cleaner Production, 170, 1399-1403. https://doi.org/10. 1016/j.jclepro.2017.09.226

Salazar, J. M., \& Leihy, P. S. (2017). El largo viaje: Los esquemas de coordinación de la educación superior chilena en perspectiva. Education Policy Analysis Archives/Archivos Analíticos de Políticas Educativas, 25 (4):1-29. https://doi.org/10.14507/epaa.25.2550 
Sardar, Z. (2010). The Namesake: Futures; futures studies; futurology; futuristic; foresight- What's in a name? Futures, 42(3), 177-184. https://doi.org/10.1016/j.futures.2009.11.001

Serrano, S. (2016). Universidad y nación: Chile en el siglo XIX. Editorial Universitaria de Chile.

Schreier, M. (2014). Chapter 12: Qualitative content analysis. In Flick, U (2014) The SAGE handbook of qualitative data analysis (pp 170 - 183). SAGE.

Sigahi, T. F. A. C., \& Saltorato, P. (2020). Academic capitalism: Distinguishing without disjoining through classification schemes. Higher Education, 80(1), 95-117. https://doi.org/10.1007/s10734-019-00467-4

Slaughter, S., \& Leslie, L. L. (1997). Academic capitalism: Politics, policies, and the entrepreneurial university. Johns Hopkins University Press.

Slaughter, S., \& Leslie, L. L. (2001). Expanding and elaborating the concept of academic capitalism. Organization, 8(2), 154-161. https://doi.org/10.1177/1350508401082003

Slaughter, S., y Rhoades, G. (2004). Academic capitalism and the new economy: Markets, state and higher education. John Hopkins University Press

Slaughter, S., \& Taylor, B. J. (2016). Conclusion. Academic capitalism, stratification, and resistance: Synthesis and future research. In Slaughter, S., \& Taylor, B. J. (Eds.), Higher education, stratification, and workforce development (pp. 349-360). Springer International Publishing. https://doi.org/10.1007/ 978-3-319-21512-9_18

Streck, D. R. (2021). Transdisciplinarity as a decolonizing research practice: A Latin American perspective. Diálogos Latinoamericanos, 29, 88-100. Retrieved from https://tidsskrift.dk/dialogos/article/view/ 120252. Accessed Oct 2021.

Spaapen, J., Vienni Baptista, B., Buchner, A., \& Pohl, C. (2020). Report on survey among interdisciplinary and transdisciplinary researchers and post-survey interviews with policy stakeholders [Report]. https:// doi.org/10.5281/zenodo.3824727

Statutes of the Universidad de Chile. (1982). Fija texto refundido, coordinado y sistematizado del decreto con fuerza de ley no. 153, de 1981, que establece los Estatutos de la Universidad de Chile. Decreto con Fuerza de ley No3. (1982/mod.2007). Biblioteca del Senado. http://bcn.cl/2lbn5. Accessed Feb 2020.

Strauss, A., \& Corbin, J. (1998). Basics of qualitative research: Techniques and procedures for developing grounded theory. Sage publications Thousand Oaks.

Taylor, B. J. (2016). The field dynamics of stratification among US research universities: The expansion of federal support for academic research, 2000-2008. In Slaughter, S., \& Taylor, B. J.(Eds.), Higher Education, Stratification, and Workforce Development: Competitive Advantage in Europe, the US, and Canada (pp. 59-79). Springer International Publishing. https://doi.org/10.1007/978-3-319-21512-9_4

Universidad de Chile (2015). Plataformas Colaborativas de Conocimiento. Un aporte transdisciplinar para Chile. Manuscript.

Universidad de Chile (2017). Plan de Desarrollo Institucional 2017-2026, Universidad de Chile. https:// uchile.cl/u30784. Accessed Feb 2020.

Universidad de Chile (2018a). Modelo Educativo de la Universidad de Chile. Universidad de Chile. https:// doi.org/10.34720/752r-ba34

Universidad de Chile (2018b). Vocación por la calidad: Resumen Ejecutivo del Informe de Evaluación Interna. Universidad de Chile. https://doi.org/10.34720/z27c-hc21

Universidad de Chile (2021). Transdisciplina en la Universidad de Chile. http://redesvid.uchile.cl/transdisci plina/. Accessed Oct 2021.

Vicerrectoría de Investigación y Desarrollo (VID) (2018). Capítulo 6. Informe de Acreditación Institucional Investigación, innovación y creación artística. Universidad de Chile.

Vienni Baptista, B. V., Vasen, F., \& Villa Soto, J. C.(2018). Interdisciplinary centers in Latin American universities: The challenges of institutionalization. Higher Education Policy, 32(3), 461-483. https://doi. org/10.1057/s41307-018-0092-X

Vienni Baptista, B., \& Rojas-Castro, S. (2019). Transdisciplinary institutionalization in higher education: A two-level analysis. Studies in Higher Education, 45(6), 1075-1092. https://doi.org/10.1080/03075079. 2019.1593347

Vienni Baptista B., Goñi M. \& Ferrigno F. (2020). Transdisciplinary communication in research teams: Institutional constructs and practices from a Uruguayan perspective. Science of Team Science Conference (online) "Excellence in Studying, Teaching, and Doing Team Science", Duke University, US, June $1-4,2020$.

Vilsmaier, U., Brandner, V., \& Engbers, M. (2017). Research in-between: The constitutive role of cultural differences in transdisciplinarity. Transdisciplinary Journal of Engineering \& Science, 8(1), 169-179. https://doi.org/10.22545/2017/00093

Yin, R. K. (2004). The Case Study Anthology. SAGE

Young, J. C., Waylen, K. A., Sarkki, S., Albon, S., Bainbridge, I., Balian, E., Davidson, J., Edwards, D., Fairley, R., Margerison, C., McCracken, D., Owen, R., Quine, C. P., Stewart-Roper, C., Thompson, 
D., Tinch, R., Van den Hove, S., \& Watt, A. (2014). Improving the science-policy dialogue to meet the challenges of biodiversity conservation: Having conversations rather than talking at one-another. Biodiversity and Conservation, 23(2), 387-404. https://doi.org/10.1007/s10531-013-0607-0

Publisher's note Springer Nature remains neutral with regard to jurisdictional claims in published maps and institutional affiliations. 